\title{
Live-trapping in the stalk zone of tall grasses as an effective way of monitoring harvest mice (Micromys minutus)
}

\author{
Esther F. Kettel ${ }^{1,2} \cdot$ Martin R. Perrow $^{3} \cdot$ Tom Reader $^{1}$ \\ Received: 24 July 2015 / Accepted: 3 January 2016 / Published online: 19 January 2016 \\ (C) The Author(s) 2016. This article is published with open access at Springerlink.com
}

\begin{abstract}
The harvest mouse (Micromys minutus) is understudied compared to other small mammals as a result of its small size and scansorial habits. This study in wetlands dominated by common reed (Phragmites australis) compared nest census, a commonly used technique to confirm presence/ absence and monitor populations, with live-trapping using Longworths and a home-made alternative trap (the Jordan trap) set both on the ground and in the stalk zone ( $1 \mathrm{~m}$ from ground or water level). Nests were found at only two of the four study sites, which may have suggested an absence of the species. However, harvest mice were caught in traps at all sites. All 108 captures of 39 individuals were made in aerial traps in the stalk zone with none caught in ground traps. Generalised linear mixed model (GLMM) also showed that significantly more captures were made in Longworth traps compared to the Jordan trap, although the efficiency of the latter increased after modification. There were also significant differences in capture rate between sites and season and a preference for higher reed quality as described by PCA in the wetter areas of the reed-beds studied. We conclude that livetrapping is preferable to nest census as a population monitoring technique and that future studies of harvest mice,
\end{abstract}

Esther F. Kettel

esther.kette102@ntu.ac.uk

1 School of Life Sciences, University of Nottingham, Nottingham NG7 2RD, UK

2 Present address: School of Animal, Rural and Environmental Sciences, Nottingham Trent University, Brackenhurst Campus, Nottinghamshire NG25 0QF, UK

3 ECON Ecological Consultancy Ltd., Unit 7, Octagon Business Park, Little Plumstead, Norwich, Norfolk NR13 5FH, UK especially in tall wetland vegetation, should use Longworth traps and/or cheaper home-made alternatives set in the stalk zone.

Keywords Harvest mice $\cdot$ Live-trapping $\cdot$ Reed-beds · Small mammals $\cdot$ Longworth trap $\cdot$ Wetland

\section{Introduction}

The harvest mouse (Micromys minutus) is the smallest rodent in Europe with an average adult weight of 6-7 g. Small size and a partly prehensile tail are adaptations to a scansorial lifestyle in the stalk zones of vegetation (Harris 1979). This specific habitat preference makes it difficult to detect using conventional live-trapping techniques, which tend to place traps at ground level (e.g. Riordan et al. 2007; Poulton and Turner 2009), and thus it is understudied in comparison with other small mammals in the UK. Searching for the distinctive nests of woven grasses is the principal method used for monitoring the distribution, abundance and population trends of the species. However, as nests can often be missed (Poulton and Turner 2009), the method may only weakly predict population size (Riordan et al. 2009) and does not provide detailed ecological information (Hare 2005). In recognition of the issues, Perrow and Jowitt (1995) used a home-made trap, the Jordan trap, developed for use off the ground in their studies of small mammals in wetlands dominated by common reeds (Phragmites australis) and other tall grasses. The Jordan trap is constructed from a $20 \mathrm{~cm}$ length of plastic drainpipe with the door and back of the trap made from square wire mesh $(6 \mathrm{~mm})$ and a simple internal treadle design made of steel wire. Bait is placed through the mesh at the back of the trap and held in place by a plastic tray. Bedding in the form of compressed 
cotton wool is placed through the front and pushed to the back of the trap to sit above the bait.

We sought to test the efficiency of the Jordan trap with the commercially available Longworth trap, with both types deployed at and above ground level in reed-beds in the English Midlands. Nest census was also conducted for comparative purposes.

\section{Study area}

The study was undertaken at two nature reserves, Attenborough (AB) and Skylarks, over three trapping sessions, with one each in autumn (October-December 2013), winter (January-February 2014), and spring (April-May 2014). Skylarks was divided in to three separate sites: Old Skylarks (OS), reed-bed of 0.3 ha adjacent to a small woodland, and New Skylarks (NS), two isolated patches of reed fringing water bodies of 0.3 (NS 1) and 0.2 ha (NS 2), respectively. The 1.5-ha reed-bed at Attenborough was adjacent to woodland and large areas of open water. All sites were known to support harvest mouse populations through previous sightings or nest searches.

\section{Methods}

Sites were sampled with a series of trapping stations at $10 \mathrm{~m}$ intervals in a grid (AB and $\mathrm{OS}$ ) or linear transects (NS). Both Jordan and Longworth traps were deployed at each trapping station with one trap placed on the ground and one trap attached to a bamboo cane using electrical tape, at approximately $1 \mathrm{~m}$ above the water or ground. The position of the Longworth and Jordan traps was alternated at sequential trapping stations. All sites were wet with fluctuating water levels, which limited the deployment of ground traps in different sessions and, in some cases, even reduced the number of usable trapping locations. The aim of using equal numbers of Longworth and Jordan traps at each site was foiled by the removal of some of the latter at NS in two trapping sessions.

Each trapping session was undertaken over four nights, with traps baited but not set to catch on the first night. A mixture of small seeds (sold commercially for parakeets), sunflower seeds and blowfly pupae was used as bait. For each of the subsequent three nights traps were checked and re-set from first light. Captured animals were identified, sexed and weighed, with all harvest mice given an individual fur clip.

During the first trapping session at each site, Jordan traps were less effective than Longworth traps, seemingly because the bait could be removed by birds and small mammals without capture. Hence, for subsequent trapping sessions, a modified version of the trap was used. The wire mesh at the back was replaced with a further offset section of drainpipe with a cap that extended the trap and allowed for more bedding and bait to be added, and prevented the latter from being removed by animals outside the trap (Fig. 1). Two small holes were also drilled in the base of the added section for added ventilation and drainage.

To help examine habitat preference in harvest mice, physical indicators of reed-bed 'quality' were measured following Hawke and José (2011). At each trapping station, a $1 \mathrm{~m}^{2}$ quadrat was placed randomly in undisturbed vegetation within $1 \mathrm{~m}$ from the traps. Within this quadrat, the total numbers of stems was counted and the height $(\mathrm{cm})$ and basal stem thickness $(\mathrm{mm})$ of five stems and the depth of water $(\mathrm{cm})$ were measured. All plant, moss and lichen species within $2 \mathrm{~m}$ of the station were noted to estimate species richness. A principal component analysis (PCA) was carried out using SPSS ${ }^{\circledR}$ Version 22 (SPSS Inc., Chicago, IL, USA) to reduce the dimensionality of the interrelated variables (reed density, average reed height and width, water depth and plant species richness), creating a single new principle component capturing $40 \%$ of the variance amongst the variables. This component correlated negatively with plant species richness and positively with reed density and reed height and hence can be interpreted as a measure of 'reed quality'. Thus, sites with positive component scores were dominated by tall, dense common reed, whilst sites with negative component scores were relatively diverse, with relatively few, short reed stems.

The catch per unit effort (CPUE) was calculated as the number of captures for harvest mouse divided by the number of trap nights. Each trap that was sprung without capture of a harvest mouse was corrected by considering this to reduce effective effort by half on the night concerned after Nelson and Clark (1973).

To test the effect of various explanatory variables on the probability of catching a harvest mouse, a generalised linear mixed model (GLMM) was fitted, assuming binomial errors, using R Version 3.0.3 (R Core Team, 2014). Trap type, elevation, trapping session, site and reed quality were fitted as fixed effects, with trap location within the grid as a random effect. All two-way interactions were considered, but higher-order interactions were ignored.

Nest searches were carried out in autumn when they are most likely to be found (Bence et al. 2003). The same transect routes used during trapping were followed during nest searches in order to minimise disruption to the habitat. It was possible to see approximately $2 \mathrm{~m}$ either side of the transect, meaning that a large proportion of the reed-bed was covered by the search. 
Fig. 1 Illustration of the outside (a) and inside (b) of the homemade Jordan trap. The drainpipe offset and end cap were added on the second and third visits to improve catch rate

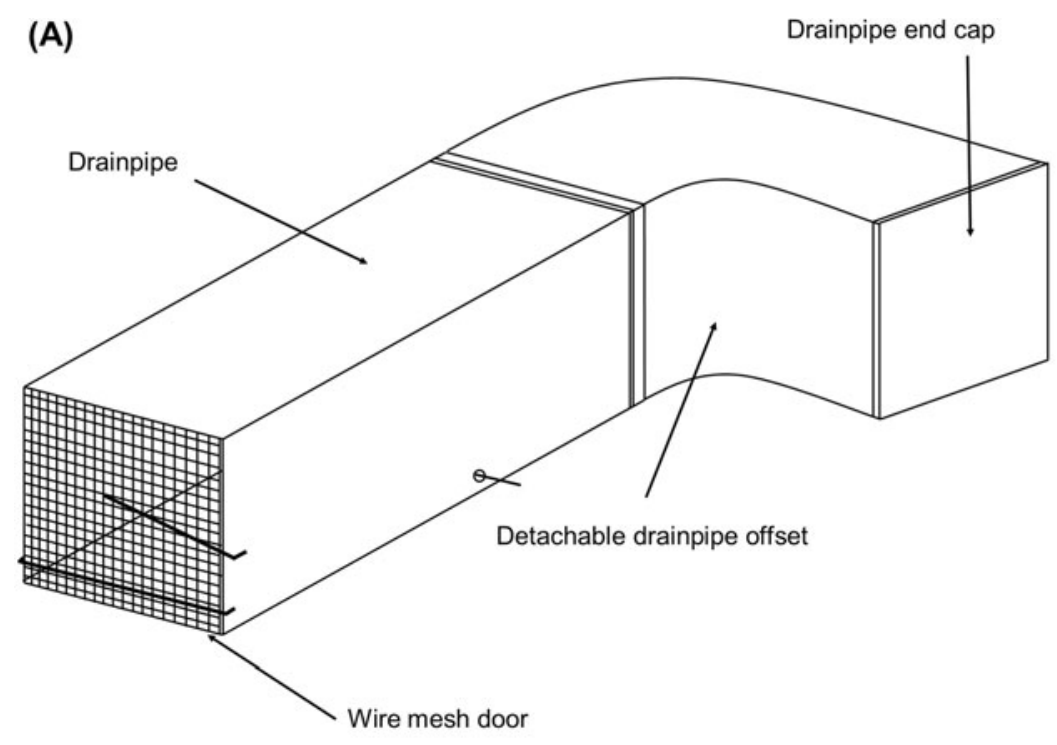

(B)

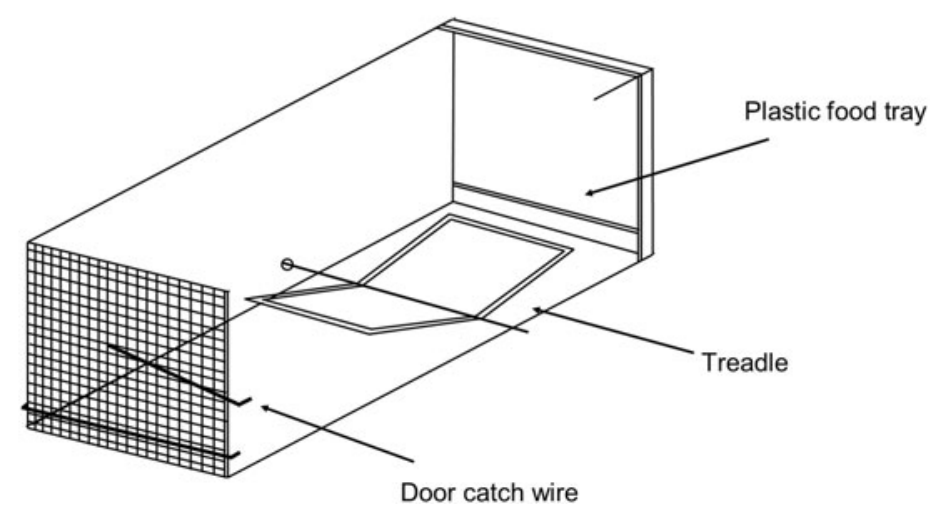

\section{Results}

Harvest mice were recorded at all sites, with a total of 108 captures of 39 individuals made over the 1751 trap night effort. Only wood mouse (Apodemus sylvaticus) was more commonly caught ( $n=243$ captures). Bank vole (Myodes glareolus; $n=100$ ), field vole (Microtus agrestis; $n=48$ ) and common shrew (Sorex araneus; $n=12$ ) were also captured (Fig. 2a).

As the only species captured exclusively in 'aerial' traps, there was a strong significant effect of elevation on the probability that a harvest mouse was captured (GLMM, $\left.X_{(1)}^{2}=17.04, P<0.001\right)$. Overall, harvest mice were significantly more likely to be caught in Longworth traps compared to Jordan traps $\left(X_{(1)}^{2}=29.172, P<0.001\right)$, but there was no significant interaction between trap type and elevation $\left(X_{(1)}^{2}=0.0022, P=0.963\right)$ or trap type and site $\left(X_{(3)}^{2}=4.960\right.$, $P=0.175)$. However, there was a significant interaction between trap type and trapping session $\left(X^{2}{ }_{(1)}=8.348\right.$, $P=0.004$ ), following an improvement in the efficiency of Jordan traps during sessions 2 and 3, after modification (Fig. 2b). Pairwise comparisons showed that Longworth traps were still more effective than Jordan traps in both trapping sessions two and three $(z$ tests, $P<0.05)$.

Overall, the probability of capturing a harvest mouse declined significantly during the study $\left(X^{2}{ }_{(1)}<4.9921\right.$, $P=0.025$ ), presumably as populations reduced following winter mortality. There was no significant interaction between elevation and trapping session $\left(X^{2}{ }_{(1)}=0.047, P=0.828\right)$ or elevation and site $\left(X^{2}{ }_{(3)}=0.013, P=0.99\right)$. There was, however, a significant difference between sites (GLMM, $\left.X^{2}{ }_{(3)}=31.233, P<0.001\right)$ with $\mathrm{AB}$ recording the highest probability of capture; modest numbers were captured at OS and NS 1, whilst harvest mice were caught only three times at NS 2. This was thought to relate to differences in habitat quality between sites as harvest mice were significantly more likely to be captured at trapping points with higher reed quality $\left(X_{(1)}^{2}=23.014, P<0.001\right)$, i.e. they were more likely to be caught in wet areas that had dense, thicker and taller reeds and fewer plant species.

Just two nests were found during searches, both at NS 2, which had the lowest number of total captures $(n=3)$. Two further nests were found by chance during trapping sessions (one in autumn and one in spring), with one each at NS 2 and 
Fig. 2 The catch per unit effort (number of captures divided by the number of trap nights) of all species caught in ground and aerial traps during the study period (a) and the proportion of Longworth and Jordan traps which caught a harvest mouse during the different seasons surveyed. Error bars show $95 \%$ confidence intervals calculated from the binomial distribution (b)

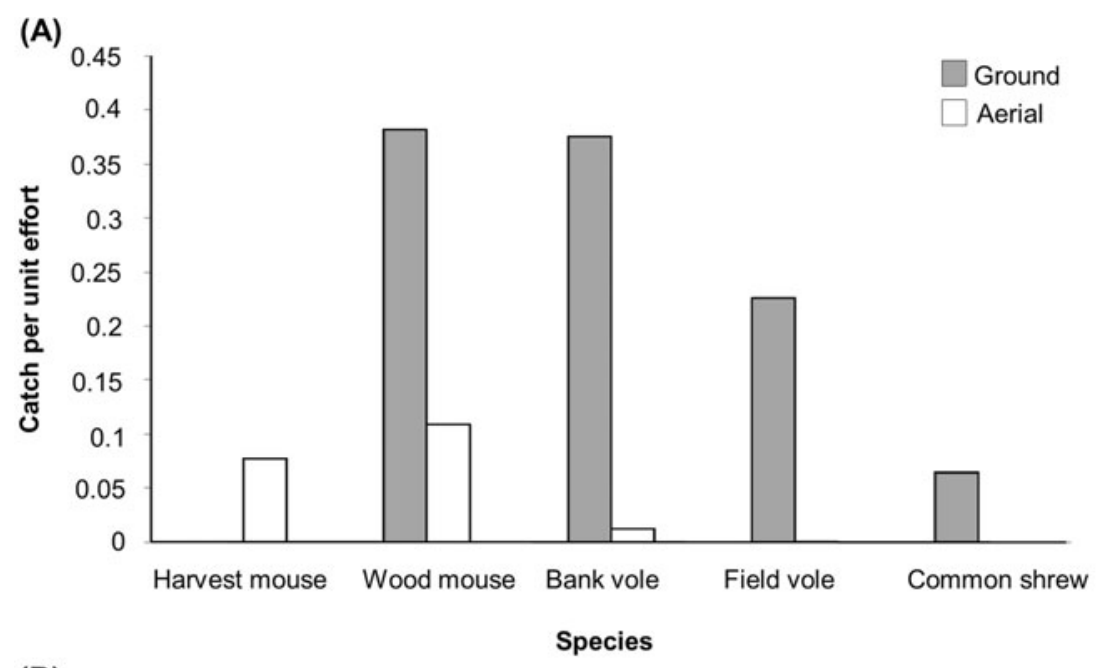

(B)

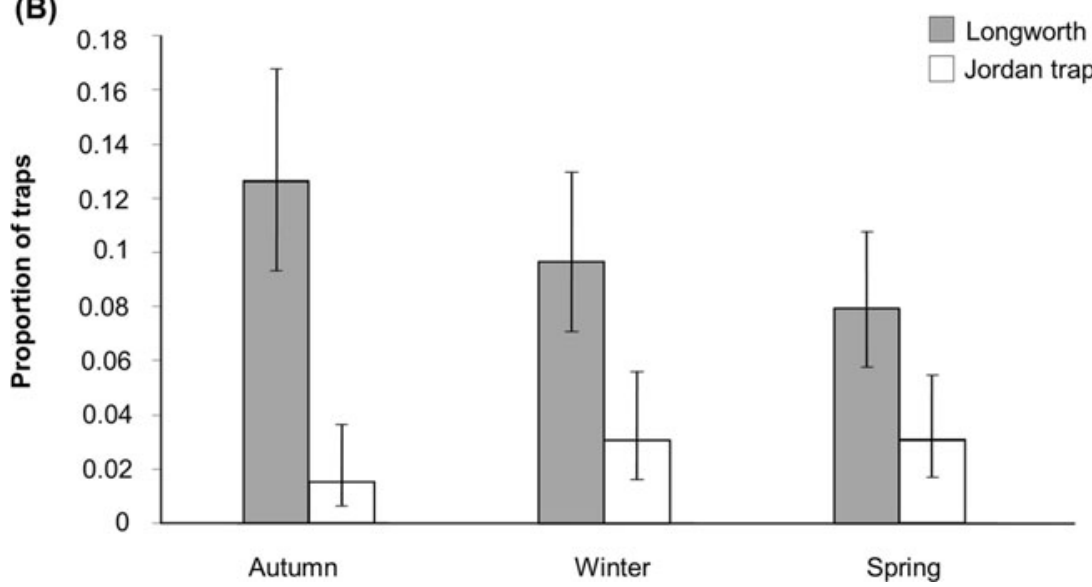

another at $\mathrm{AB}$, where harvest mice were most commonly recorded ( $n=72$ total captures). Thus, no nests were found at two of the sites (OS and NS 1) despite the known presence of harvest mice from trapping ( $n=19$ and 14 total captures respectively).

\section{Discussion}

Our study tends to support the findings of a number of other authors (e.g. Pelikan 1975; Saint-Girons 1981; Perrow and Jowitt 1995, 2003; Surmacki et al. 2005) that reed-beds are a good, if not excellent, habitat for harvest mice. Captures were associated with reed quality, which in turn was linked to the wetter parts of the reed-beds or emergent zone around the waterbodies sampled. Accordingly, like Pelikan (1975) and Perrow \& Jowitt $(1995,2003)$, we regularly captured the species in the stalk zone including over standing water. In contrast, Surmacki et al. (2005) suggested that harvest mice prefer the drier parts of reed-beds. The discrepancy between the studies may be because Surmacki et al. (2005) used the location of breeding nests to indicate habitat preferences, which may only reflect nesting habitat rather than more general habitat use.
Moreover, we did not sample in the summer breeding period when mice may show different habitat preferences. This may also partly account for the extremely low frequency of detection of nests in our study. Whatever the reason behind the lack of nests, our results strongly suggest that nest counts are of extremely limited value in predicting population size, reinforcing the conclusions of Riordan et al. (2009). Critically, nest census may fail to detect harvest mouse at all.

In order to detect harvest mice, Dickman (1986) and Perrow \& Jowitt (1995) used hair tubes to sample the distinctive guard hairs of the species. However, there is as yet, little information on how the frequency of occurrence in hair tubes relates to abundance, and live-trapping appears to provide the best prospect of estimating population size. But, conventional ground trapping would have missed harvest mice at all of the sites in this study, despite trapping in several seasons to combat any changes in habitat use. Harvest mice have been captured on the ground in other studies, and indeed, it was the most frequently caught species in new woodland plantation sampled by Moore et al. (2003). Habitat type, especially the height of grassy vegetation, may thus influence catch rate on the ground. In a range of wetland vegetation types trapped across all seasons, $24 \%$ of all harvest mice captured 
$(n=1947)$ were in traps at or near ground level (Perrow \& Jowitt 1995). The wet reed-beds in our study may represent an extreme case, where harvest mice are forced to use the stalk zone or at least any leaf litter present above standing water. To better understand use of such habitats in future, we suggest placing traps on small floating rafts.

Although it has been previously recognised that studies of harvest mice should use traps sampling the stalk zone, this has been of limited success (Riordan et al. 2007; Poulton and Turner 2009). Our study shows that the Longworth trap may be successfully deployed, with its relatively sensitive treadle mechanism compared to other commercially available designs such as the Sherman trap, being key to sample small species (Anthony et al. 2005). The high cost of Longworth traps (currently £60 in the UK), as well as their attractiveness to thieves, may limit largescale studies in particular. Although we found that Longworth traps were significantly more likely to capture harvest mice than the home-made Jordan trap, this difference reduced after modification. Key features of the Jordan trap are that the sensitivity of the treadle is easily adjusted by simply bending the wire, and the trap may be adapted (e.g., the angle it is set, and orientation to the wind) to suit the specific circumstances. We are therefore confident that with further modification, the Jordan trap or indeed other home-made alternative traps of similar design could match the efficiency of the Longworth trap and be used to contribute to the scarce body of knowledge on the ecology of harvest mice and help us to better understand its conservation status.

Acknowledgments We are grateful to everyone who helped with fieldwork: Matthew Edwards, Philip Bych, Marie Athorn, Charlotte James, Lorna Griffiths, Courtenay Holden, Bethany Kettel and Neil Pinder who helped with nest searches. We also thank Toby Tonkin for his useful comments on the manuscript and Nottinghamshire Wildlife Trust for allowing us to carry out research on its reserves. Finally, we thank Dr Christian Gortázar for handling the manuscript.

Compliance with ethical standards In this study, in research involving human participants and/or animals, all applicable international, national, and/or institutional guidelines for the care and use of animals were followed.

Open Access This article is distributed under the terms of the Creative Commons Attribution 4.0 International License (http:// creativecommons.org/licenses/by/4.0/), which permits unrestricted use, distribution, and reproduction in any medium, provided you give appropriate credit to the original author(s) and the source, provide a link to the Creative Commons license, and indicate if changes were made.

\section{References}

Anthony NM, Ribic CA, Bautz R, Garland T (2005) Comparative effectiveness of Longworth and Sherman live traps. Wildlife Soc Bull 33: 1018-1026

Bence SL, Stander K, Griffiths M (2003) Habitat characteristics of harvest mouse nests on arable farmland. Agric Ecosyst Environ 99: 179-186

Dickman CR (1986) Habitat utilisation and diet of the harvest mouse, Micromys minutus, in an urban environment. Acta Theriol 31:249256

Hare, E (2005) An analysis of small mammal indirect sampling methodology in hedgerows. A report to the Mammals Trust. 19

Harris S (1979) The secret life of the harvest mouse. The Hamlyn Publishing Group Ltd., London

Hawke CJ, José PV (2011) Reedbed management for commercial and wildlife interests. The Royal Society for the Protection of Birds, Bedfordshire

Moore NP, Askew N, Bishop JD (2003) Small mammals in new farm woodlands. Mammal Rev 33:101-104. doi:10.1046/j.1365-2907. 2003.00004.x

Nelson L, Clark FW (1973) Correction for sprung traps in catch/effort calculations of trapping results. J Mammal 54:295-298. doi:10. $2307 / 1378903$

Pelikan J (1975) Mammals of Nesyt fishpond, their ecology and production. Acta Scientifica Naturalium BRNO 9:1-45

Perrow MR, Jowitt AJD (1995) What future for the harvest mouse? Br Wildl 6:356-365

Perrow MR, Jowitt AJD (2003) Wetlands as an important habitat for small mammals. Br Wildl 14:171-179

Poulton S, Turner P (2009) A comparison of nest searches, bait tubes and live trapping for monitoring the harvest mouse (Micromys minutus) and other small mammals. Mamm Soc Res Rep Number 9:9

R Core Team. (2014) R: A language and environment for statistical computing. R Foundation for Statistical Computing, Vienna, Austria. Available at URL: http://www.R-project.org/

Riordan, P, Lloyd, A, Macdonald DW (2007) The status of the harvest mouse (Micromys minutus) in a lowland agricultural landscape. A Report to the People's Trust for Endangered Species. 35

Riordan P, Lloyd A, Macdonald DW (2009) Do harvest mouse nest survey results predict population size? A report to the people's trust for endangered species. 10

Saint-Girons MC (1981) Notes sur les mammifères de France, XIV, Le rat des moissons, Micromys minutus et le développement des cultures de mais. Mammalia 45:493-496. doi:10.1515/mamm.1981.45.4. 493

Surmacki A, Gołdyn B, Tryjanowski P (2005) Location and habitat characteristics of the breeding nests of the harvest mouse (Micromys minutus) in the reed-beds of an intensively used farmland. Mammalia 69:5-9. doi:10.1515/mamm.2005.001 